Információközvetítés és közösségépítés - multifunkciós könyvtári hálózatok.

Szerk. Kiszl Péter, Németh Katalin. Budapest, ELTE BTK

Könyvtár- és Információtudományi Intézet. 2020. 135-147.

\title{
TUDÁSBÁZISOK SZEREPE AZ EGYHÁZI HIVATÁSÚAK ÉLETHOSSZIG TARTÓ TANULÁSÁNAK TÁMOGATÁSÁBAN
}

\author{
MÉSZÁROS KoRNÉLIA
}

\section{TARTALMI ÖSSZEFOGLALÓ}

Az egyház feladatából adódóan a gyülekezeti-, oktató-nevelő, valamint a diakóniai területen végez kiemelt munkát. Az elmúlt években zajló oktató-nevelő- és szociális intézmény-átvételek talán még fontosabbá tették az egyházi intézményekben dolgozó szakemberek szakmai felkészültségének támogatását, a megfelelő képzések, továbbképzések és az önképzés lehetöségének biztosítását. A tanulmány az egyházhoz kapcsolódó hivatásban állók továbbképzési, önképzési és szakmai fejlődési lehetőségeit kutatja, és vizsgálja az egyházi felsőoktatási intézmények és könyvtáraik e körben végzett tudás- és tanulástámogató szerepét.

Miért jó a könyvtár? Miért fontos az egyházi/teológiai szakkönyvtár? Milyen kapcsolatban áll egyetem és könyvtár? Hogyan tudja segíteni, útba igazítani egyik „útkereső” a másikat? Milyen információkeresési attitüdök jellemzik az egyház munkatársait? Releváns támasz tud-e lenni a könyvtár az egyházi szolgálatban állók számára? Az információs technológia és a tudományos kommunikáció világában történt változások számos szakma elé helyeztek kihívásokat, így került kérdőjel a könyvtárak jövője és a könyvtáros szakemberek szerepe mellé is, de hasonló helyzetben vannak a pedagógus, valamint a lelkész hivatást választók is. Ha az egyház a mai posztmodern világban is hirdetni akarja az evangéliumot, szolgálni az elesetteket, oktatni és nevelni, akkor feladata, hogy az általa fenntartott intézményekben dolgozó szakemberek számára biztosítsa a szellemi és lelki feltöltődést, a képzés, az önképzés és továbbképzés lehetőségét, és megkeresse ezen feltöltődési- és képzési formák módjait; praktikusan saját felsőoktatási intézményét és saját gyüjteményeit (legfőképpen tudományos szakkönyvtárait).

„Adj a bölcsnek, és még bölcsebb lesz, tanitsd az igazat, és ő gyarapítja tudását!"

Péld 9,10

\section{Az egyházi szolgálat és a protestáns hivatásértelmezés}

A vallás szerves része a társadalomnak, világméretü jelenség, ezért relevanciáját nem lehet figyelmen kívül hagyni. A legtöbb vallásban fontos szerepet tölt be a szolgáló „klérus”, akik felelősséggel tartoznak híveikért. A történelem során sok foglalkozás szerepe és feladatköre átalakult, az idők változásával új tevékenységi körök, más megközelítési módok lettek hangsúlyosak. Nincs ez másképpen az egyházhoz kapcsolódó 


\section{MÉsZÁros KoRNÉLIA}

foglalkozásokkal, hivatásokkal sem. Már kezdetektől fogva látszik, hogy az egyházi küldetés betöltésének sokféle formája van, de minden szolgálat alapfeltétele a Krisztussal való kapcsolat. Míg az Ószövetségben néhány kiválasztottnak adatott meg, hogy prófétaként, papként vagy királyként különös elhívásban részesüljön, addig az Újszövetségben már minden hívő kap hívást Isten országának hirdetésére. ${ }^{1}$

Az idők során nemcsak az egyházi szolgálat változott, hanem a keresztény közösség megélése és a közösség életében betöltött szerepek is változtak és átalakultak. ${ }^{2} \mathrm{Az}$ apostolok és próféták fontos szerepet töltöttek be az egyház korai életében, a tanítók feladata az újonnan megtértek segítése, az összes többi ajándék pedig a már működő gyülekezet életét volt hivatott segíteni. ${ }^{3}$ A feladatok alakulásával az egyházi szolgálat föbb típusai az alábbiak szerint kerültek meghatározásra: az Ige szolgálata (apostolok, tanítók, próféták, evangélisták), a gyógyítás szolgálata (diakónusok), a vezetés szolgálata (püspök, presbiterek) és egyéb, a közösség felé végzett szolgálat (nyelveken szólás, a nyelveken szólás megmagyarázása stb.). „Minden esetben fontos, hogy a hivatal betöltője részesüljön a Szentlélek ajándékában, és az egyház imádság és kézrátétel által felismerve Isten akaratát, elismerje az elhívott személyeket a közösségi funkciók betöltőiként."4

Luther újat hozott az egyház hivatásértelmezésében. A reformációig az a szolgálat, amit a felszentelt személyek végeztek, magasabb rendűnek számított, mint a laikusok által végzett munka. Luther értelmezésében sem a klerikusok, sem pedig az általuk végzett feladatok magasabb rendűsége nem szerepel. Meglátása szerint a legtöbb foglalkozás Isten számára kedves és előtte értékbeli különbség nincs a szakmák között: „Isten szorgalmat és hüséget követel minden hivatásban.”5 Luthernél és Kálvinnál az Isten dicsőítésére gyakorolható a legtöbb emberi hivatás (lásd: a keresztény ember számára a munka istentisztelet), így szoros összefüggésben maradva az elhívóval, Istennel. A hivatás Istentől kijelölt hely, éppen ezért minden egyes hivatásnak, még a legegyszerübbnek is, megvan az értéke. ${ }^{6}$

\section{A tudás és az információ szerepe az egyházi hivatásúak körében}

Az egyházi környezetben mindig fontos volt a kutatás, az oktatás, a tudás továbbadása, így a könyvtárak a szerzetesi közösségek, a lelkészlakások és paplakok elengedhetetlen részei voltak. A lelkészek, tanítók, orvosok korábbi századokból ismert tudásbeli monopolhelyzete azonban megszűnt. Manapság az információ egy karnyújtásnyira van a keresőtől. Egy kattintással kereshetünk válaszokat teológiai kérdéseinkre, az érdeklődési körünknek megfelelően számos oktatóvideóból válogathatunk, a betegségeink kezelésében pedig azonnal rendelkezésünkre áll „Dr. Google”. A lelkészek, pedagógusok és orvosok így minden nap, minden korosztállyal, vagy bármely társadalmi réteggel találkozva egyfajta vizsgahelyzetben vannak. Ebben a helyzetben különösen szükség van a szakképzés minőségének biztosítására és a folyamatos önképzésre.7 
Ahhoz, hogy munkájukat szakszerüen lássák el, és mindennapi feladataik elvégzésében hatékonyak legyenek, az egyházi hivatásúak számára is szükséges a vallási és világi információkhoz való hozzáférés. Bár az információ fontos szerepet tölt be a vallásban és a világ számos vallási bölcselöje számára nélkülözhetetlen, mégis meglepő tény, hogy eddig csak néhány olyan tanulmány született, amely az egyházi hivatásúak információkeresési szokásait és viselkedését vizsgálta - hívja fel a figyelmet cikkében Jacob Dankasa, aki katolikus papként tanulmányozza a kérdést. ${ }^{8} \mathrm{Az}$ eddigi felmérések közül több is megállapította, hogy jelentős kapcsolat alakult ki egy adott egyházi személy beosztása és az információkereső magatartás között, és kiderült, hogy a papság egyre inkább az internetes forrásokat használja a szolgálatra való készülés során. ${ }^{9}$ A kutatók közül Donald Wicks tanulmánya ${ }^{10}$ is megerősítette, hogy az információkeresési folyamat változik attól függően, hogy milyen szerepet tölt be az illető; vagyis különböző munkakörökben különböző forrásokat használ. A tanulmány kimutatta, hogy a prédikáció és más teológiai információk esetében a lelkészek a könyveikre támaszkodnak, az adminisztrációs feladatok elvégzésében, vagy a helyi egyházi információkkal kapcsolatosan azonban az interperszonális források felé fordulnak információért. Dankasa megállapítja, hogy a már meglévő kutatások mellett továbbiakra lenne szükség ahhoz, hogy ezen célcsoport információkeresési szokásai alapján a könyvtárak és internetes tartalomfejlesztők sikeresebben tervezzék és rendezzék az információ szolgáltatását. ${ }^{11}$

\section{A szakmai igényesség alapvetései}

Minden szakma esetében fontos a szakmai igényesség, így az egyházi szolgálat során is. Még akkor is, ha sok esetben a társadalom szempontjából mára már egyre nagyobb hangsúly került a pedagógus, diakóniai munkatárs és lelkész személyiségének kérdésére (mennyire kedves, empatikus, szerethető, illetve vonzó személyiség). „Nem biztos, hogy minden lelkész teológus akar lenni, a teológus szónak a teológiai tudományt müvelő embert jelentő értelmében. De minden lelkésznek mégis teológusnak kell lennie nemcsak abban az értelemben, hogy vannak bizonyos teológiai ismeretei, hanem abban az értelemben is, hogy teológusként közelít meg kérdéseket és van teológiai ítélőképessége. [...] Különösen igaz ez, ha nemcsak a bibliai szöveg megértésében (exegézisében) mélyed el, hanem utánanéz egyháztörténeti vonatkozású illusztrációknak, a felvetődő dogmatikai vagy a textusból következő etikai kérdéseknek."'12

A pedagógusok esetében szintén fontos alapelv a szakmai igényesség, hiszen egyházi oktatási-nevelési intézményekben ma is sok tudományos fokozattal rendelkező tanár tanít. „Közülük sokan rendszeresen publikálnak, hazai és nemzetközi konferenciák előadói, többen a Magyar Tudományos Akadémiai Pedagógus Kutatói Pályadíjjal kitüntetett pedagógusai, kiváló szakemberek, akik mindennapos oktató-nevelő munkájuk mellett szaktudományos kutatási eredményeket is magukénak mondhatnak."13 A diakóniai munkát végzők körében is alapvető a szakma ismerete, 


\section{MÉszÁros KorNÉLIA}

ezen kívül pedig fontos, hogy minden munkatárs rendelkezzen diakóniai alapismeretekkel. Több munkatárs a szakmai munka mellett az intézmény lelki életében is szervezetten részt vállal, közösségteremtő tevékenységet folytat. Az ő képzésük, szakmai hozzáértésük különösen is fontos. ${ }^{14}$

\section{A felsőoktatás kihívásai}

A kereszténység történetében az egyetemek már 900 éve vesznek részt a pap-, illetve lelkészképzésben. ${ }^{15} \mathrm{Az}$ egyetem- és iskolaalapítások óta eltelt hosszú idő alatt a nevelési elvek és a tudomány is átment jó néhány paradigmaváltáson. Az egyház történetének azon korszakaiban, amikor saját létéért kellett küzdenie, a tanítás prioritása mindig megerősödést és lelki gyarapodást hozott. A mai identitáskeresés szintén olyan időszak, amikor az egyháznak át kell gondolnia elhívása kontextuális megvalósulását. ${ }^{16}$

Több jel mutat arra, hogy korunkban a kultúra területén jelentős változások mennek végbe, ezzel együtt az egyetemi képzések keretén belül új paradigmák keresése indult, és ezen belül a teológiai képzés is keresi helyét az átalakuló világban. ${ }^{17}$ Ebben az útkereső, folyamatosan változó világban az egyházak által fenntartott felsőoktatási intézményeknek is új és újra feltett kérdésekre kell válaszokat adniuk:

- „Olyan okos és tájékozott emberekre van szükség, akik teológiai szempontok alapján képesek reflektálni az élet dolgaira?

- Esetleg olyan vezetőképzés helye a teológia, ahol elég ügyes és gyakorlott lehet egy fiatal, hogy akár nála 20, 30, 40 évvel idősebbek „pásztora”, illetve lelkigondozója legyen?"18

- Milyen egyházismeretre, teológiai jártasságra van szüksége egy egyházi intézményben dolgozó szociális munkásnak, ápolónak, szupervízornak, menedzsernek, pedagógusnak? Van-e szüksége ilyen jártasságra a szakfeladatok ellátásához?

- Mennyire függ az egyházi iskola a keresztény pedagógiától, és vajon szükséges-e a keresztény pedagógia megvalósításához az egyházi iskola? ${ }^{19}$

- Melyek a legkorszerübb oktatási módszerek? Elég gyorsan tudják-e ezeket a képzési tantervekbe integrálni?

Az amerikai valláspedagógus professzor, Robert W. Pazmiño szerint az oktatás és nevelés kapcsán a nevelési intézmények az alábbi három fő fókusz valamelyikét tartják elsődleges célnak: 1) Tartalomközpontú oktatás, amelynek célja elsődlegesen a tudásátadás, hogy minél több ismerethez jusson a hallgató, és minél műveltebb legyen az adott területen. 2) Az egyén igényeit figyelembe vevö oktatási módszer arra koncentrál, hogy mi az, ami a hallgatót érdekli, érinti, számára releváns és fontos. Itt az oktatás elsősorban a hallgató befogadókészségéhez, motivációjához kötődik. 3) A közösség igényeit figyelembe vevő oktatási szemlélet elsősorban arra koncentrál, hogy mi az, amire a 
közösségnek szüksége van, és nagy hangsúlyt helyez arra, hogy a hallgatók kapcsolódjanak egymáshoz, tegyenek a közösségért, legyenek felelős és aktív részesei a társadalom életének és alakítói környezetüknek. ${ }^{20}$

Az egyetemi alap- és mesterképzések során a tartalomközpontú és a közösség igényeit figyelembe vevő oktatás dominál, míg a posztgraduális képzések és továbbképzések, a specializációk, valamint a felnőttképzés során jobban felértékelödik az egyén igényeinek figyelembevétele is. A teológiai oktatás a kognitív tudás és a verbális készségek elsajátítását tartja a legfontosabbnak, azonban a teológiának a verbális és a logikai intelligencia fejlesztésen túl az inter- és intraperszonális intelligenciák területeivel, valamint a zenei készség területével is foglalkoznia kell. ${ }^{21}$ Mind a lelkész, mind a pedagógus hivatás esetében fontos - az a közösségi oldalról érkező igény -, hogy az illető „okos” ember legyen; vezetőként fontos, hogy tudjon kapcsolatot teremteni és bizalmi kapcsolatot ápolni, a lelkész esetében pedig még fontos az is, hogy Istennel való személyes kapcsolat megélője és szószólója legyen a gyülekezetben. Az egyházi szolgálat és a diakónia területén dolgozók az élet sokféle területén találkoznak az emberi esendőség és kiszolgáltatottság helyzetével. A jellemről alkotott véleményt erősen meghatározza az érzelmi intelligencia: az érzések kontrollálása, a motiváció, az érzelmi kérdésekben való segítségkérés, az impulzusok értelmezése, az empátia, figyelmesség, konstruktivitás, a konfliktus- és kríziskezelés és a különbözőség tiszteletben tartása. A hatékony keresztény vezetés ezek alapján keresi a visszajelzést munkájáról. ${ }^{22}$

De vajon, hogyan döntse el a pedagógus, lelkész, diakóniai munkatárs, hogy a róla alkotott, definiált vagy éppen definiálatlan hivatáskép és elvárás közül melyiket tekinti sajátjának és melyikkel tud, nem tud, vagy nem is akar azonosulni? Kérdés, hogy inkább sok mindenhez valamelyest értő generalistának vagy egy-egy terület specialistájának kell-e lenniük? Isolde Karle „speciális generalistának” nevezi azt a kompetenciát, amire szüksége van egy lelkipásztornak. ${ }^{23}$ Kérdés, hogy miként érhető el ez a kompetencia az egyetemi oktatás során? Mit tud tenni az egyetem annak érdekében, hogy a terepre kikerülő szakemberek megfelelö tudással végezzék a munkájukat? Mérő László szerint: „Az egyetem, azaz az universitas lényege éppen az, hogy egy általános képzést ad, amelynek segítségével a diplomásoknak meglesz az alapjuk ahhoz, hogy specialistává váljanak. [...] Az egyetemistát arra edzették öt éven át, hogy bármikor meg tudjon tanulni valami egészen újat, meglegyen hozzá az általános szakmai alapja, és legyen gyakorlata az egészen új dolgok megtanulásában. [...] Ebből a szempontból majdnem mindegy, hogy valaki a római jogból, a parciális differenciálegyenletek vagy az ószláv grammatika tanulmányozásával szerezte meg ezt a képességet. Minden egyetem esetében ez a szakmai alapozás valami olyasféle dolgokkal történik, aminek később nagy valószínüséggel nem veszi konkrét hasznát az ember. Például nem orvos az, aki nem tudta valamikor a halántékcsont összes dudorának és üregének a latin nevét - és van belőlük vagy kétszáz. Ezek még csak megbetegedni sem igen tudnak, de akkor is, az orvosnak ismerni kell az emberi test minden porcikáját. Ez alapozza 


\section{MÉszÁros KornÉLIA}

meg tudását és az általános gyógyító képességét. [...] Az egyetem generalistákat képez. Ugyanakkor aki akar, viszonylag gyorsan specialistává válhat."24

Nagyon érdekes az a református lelkészek körében készült felmérés, amelyben az egyetemi évekről, a szakmai felkészítés hasznosságáról, az ott tanultak alkalmazásáról vallanak személyes interjúkban. Az egyik interjúalany éppen a fenti tételt látszik megerősíteni. „Volt 1-2 tanár, aki iszonyatosan, tölcsérrel töltötte a fejünkbe a tudást. Nem gondolom, hogy ezzel baj volt. Ezekkel a dolgokkal kevésbé foglalkozom ma. [...] Arra viszont megtanítottak, hogy mit hol kell megtalálni, ha az ember keres.” ${ }^{25}$ Egy másik lelkész szintén az elméleti oktatás fontosságáért érvel: „Mindig megy ez a nyavalygás, hogy kéne gyakorlatot tanítani többet a teológián - nem tudom, biztos hallottad már ezt a toposzt -, ellene vagyok. Érdekes módon ellene vagyok. Szerintem sosem lesz már az embernek ideje héberezni meg görögözni, és végső soron mégiscsak teológusok vagyunk és a teológia grammatika - mondja Luther. Tehát itt gondolkodni kell, meg olvasni kell, meg szociológiai riportot csinálni. Kikerülsz segédlelkésznek és temetsz, mint az állat. Nincs többé ilyen nyavalygás. Halomban állnak a könyvek, és évek óta nem tudom végigolvasni. Tehát ez egy munka. Majd beszélünk erről is biztos... A lelkészi hivatás. [...] Kell a gyakorlat, de szerintem nem a suliban.” ${ }^{26}$ De olvashatunk más megközelítést is: „Nagyon-nagyon eszköztelen a mai lelkésztársadalom. [...] én nagyon borzasztó vagyok egzegézis, görög/héberből, de az én véleményem az, hogy teológusokat képzünk, és nem lelkészeket, és ez nem jó, mert teológusokból viszont középszerüt tudunk képezni. Tehát, hogy ez ma nem olyan nehéz, ott van a Bibleworks, kipreparálja a szöveget. Ott van egy csomó jó színvonalú, magyar nyelven is vannak jó kommentárok, de angolul meg bármikor bármi elérhető. Ezek azért olyan teológusok, akik éveket töltöttek egy páli levélnek, vagy évtizedet az értelmezésével, és hogy bizonyos szempontból többre jutottak, mint amire mi fogunk, ha nekiülünk a szövegnek. Azt gondolom, hogy ettől függetlenül ezt nem spórolnám meg, tehát ez tök jó dolog úgy készülni, hogy a szöveget kipreparálni, végignézni, de hogy nekem hiányzik az, hogy oké, de mi az a közeg, amiben mi hirdetjük az evangéliumot, mik a kérdések." ${ }^{27}$

„Sola experientia facit theologum” (WA 25; 106,27), ${ }^{28}$ vallja Luther, vagyis a gyakorlat teszi a teológust lelkésszé. A gyakorlati oktatás már az egyetemi évek alatt elkezdődik, de sok mindent a szolgálati évek alatt sajátít el az ember. Viszont a teológiai képzés is meghatározó része annak, hogyan áll majd szolgálatba a teológus. „Gyülekezeti élet és teológia közti szakadék létezik, csakúgy, mint más szakmáknál az elméleti képzés és a gyakorlati élet esetében is." ${ }^{29}$ Az egyetemen tanultak azonban fontos részét képezik a szakmára való rálátásnak, a szemléletformálásnak, hiszen a hallgató a későbbi szakmai életében az itt tanultakra épít és foglal állást. 
TUDÁSBÁZISOK SZEREPE AZ EGYHÁZI HIVATÁSÚAK ÉLETHOSSZIG TARTÓ...

\section{Könyvtárak az egyetemek életében}

A könyvtár az egyházi felsőoktatási intézmények életében kiemelt szerepet tölt be, az intézmény négy központi helye (tanterem, kápolna, terepgyakorlati helyszín, könyvtár) közül az egyik. ${ }^{30}$ Gyakran hallani könyvtáros körökben, hogy a könyvtárak nem (könyv)raktárak, hanem az információáramlás színhelyei. Feladatuk alapvetően nem a tárolásról, hanem a hozzáférés biztositásáról szól. (Nem elfelejtve azt, hogy a gördülékeny rendelkezésre bocsátás természetesen nem müködhetne a könyvtár által gyüitött különböző dokumentumok katalogizálása, osztályozása és tárolása nélkül.)

A könyvtárak felelössége, hogy a náluk fellelhető információkhoz ne csak fizikai lehetőséget, hanem szellemi támogatást is nyújtsanak. A könyvtár kulcsszerepet játszik abban, hogy fenntartsa és előmozdítsa az egyház és a felsőoktatási intézmény közötti, valamint az egyház és a teológia mint tudományterület közötti kapcsolatokat, és rávilágítson ezen kapcsolatok fontosságára. ${ }^{31}$ Ahogy „[a]z egyház szolgái jelen voltak az emberek életének nagy átmeneteiben is (születés, felnőtté válás, házasság, halál, betegség),"32 úgy kell helyt állnia, jelen lennie a könyvtárnak is az egyház szolgáinak életében már a szolgálatra való elhívástól kezdődően. Így áll rendelkezésre a hittan érettségire vagy az egyetemi felvételire való felkészülés során, s ezt követően az egyetemi tanulmányok idején, majd a szolgálatban, az élethosszig tartó tanulás során is. Ehhez számos együttmüködés szükséges már csak „házon belül” is: a hallgatókkal, az oktatókkal, a gyakorlatvezetőkkel, valamint a tanulmányi- és a gazdasági hivatallal. Ezen kívül folyamatos a kapcsolattartás az egyházzal, az egyházi intézményekkel, az egyházi és világi kiadókkal, könyvtárakkal és szakmai szervezetekkel is. Az egyetemi könyvtárnak fontos szerepe van az oktatás támogatásában, s ehhez fontos, hogy a könyvtár is aktív szereplöje legyen az intézménynek, hogy ne önálló szigetként, hanem különböző hálózatok részeként legyen jelen az intézmény életében.

A legjobb egyetemek fokmérője - legalább részben - az egyetemi információs infrastruktúra minősége lesz - állította Joe Branin 1993-ban. Az egyetemi oktatás és kutatás támogatásához nélkülözhetetlen lesz a könyvtár és az informatikaért felelös részleg hatékony együttmüködése. ${ }^{33}$ Azóta eltelt már több mint negyed évszázad, és a jóslat beigazolódni látszik. A XXI. század egyetemi könyvtárai már kevésbé gyüijteményközpontúak, inkább a tanulásra, az együttmüködésre és a tartalmak létrehozására összpontosítanak - legalábbis erre törekszenek. Ezek a könyvtárak egy olyan kultúra és közösség részei, amely elkötelezett a tanulás iránt, és a tudás létrehozásának alapelveként az eszmecserét jelöli meg. Az egyetemi könyvtárak ezt a tudományos eszmecserét proaktívan gyorsíthatják. A felsőoktatási intézmények részeiként, vagy azokhoz szorosan igazodva, az egyetemi könyvtárak átfogó gyüjteményeket szerveznek, amelyet időnként szelektálnak, és a kutatási és oktatási tudományos párbeszéd ütemének felgyorsítására törekszenek. ${ }^{34}$ Fontos, hogy a könyvtár ne csak az egyetemi curriculum által előírt szakirodalmat gyüjtse, hanem az oktatott tárgyak és azok határterületeihez 


\section{MÉsZÁros KoRNÉLIA}

kapcsolódó dokumentumokat is - nyomtatott és elektronikus tartalmakat egyaránt. Sok egyetemi könyvtár fizet elő különböző szakterületi adatbázisokra, továbbá maga is részt vesz kutatási anyagok digitális archívumainak létrehozásában, ezzel jelentősen segítve az adott terület kutatóit. Számos tudományterületnél megjelent a webalapú tudományos publikációs csatornák használata (pl.: intézményi repozitóriumok, open access folyóiratok, egyetemi közösségi hálózatok), ezzel elősegítve az aktív eszmecserén alapuló tudományos publikálás felélénkülését. Az egyetem ezen irányú misszióját segítheti a könyvtár a repozitóriumok fenntartója és üzemeltetőjeként, valamint a tudományos publikálási lehetőségek és jelenlétek új irányainak közvetítőjeként.

Ahelyett, hogy az egyetemet egyfajta kezdeti szolgáltatónak tekintenék (ami a képzés után útjára bocsátja a hallgatót), fontos lenne az egyetemre mint az élethosszig tartó tanulás, az „eszmecsere és tudásközpont” színhelyére tekinteni, ahova a hallgatók a diploma megszerzése után is visszatérhetnek különböző továbbképzésekre, átképzésekre, vagy egyszerűen csak önképzés céljából. A könyvtár-alapú oktatási innováció valódi potenciálja ebben az időszakban jelenik meg leginkább. Fontos, hogy a könyvtár ne csak egyszerüen válaszokat adjon a feltett kérdésekre, hanem megtanítsa a válaszok keresésének módját, és segítse újabb kérdések felvetését is.

\section{A túláradó információ problémája}

A tudomány exponenciális fejlődésével korunkban a megszerzett tudás ötévente megfeleződik. A versenyképességet csak úgy őrizhetjük meg, ha ismereteinket újabb és újabb információkkal, adatokkal bővítjük, frissítjük, ha lépést tartunk a tudományos eredményekkel, a tudományos fejlődéssel. ${ }^{35} \mathrm{Ez}$ a megállapítás az egyházi hivatásban állók számára is komoly kihívásokat hordoz. A szakterületen való naprakészség érdekében időt kell szakítani az önképzésre is, még a gyülekezeti, pedagógusi, diakóniai területeken fennálló túlterhelés ellenére is. A XIX-XX. század folyamán a teológia nyitott számos tudományterület felé, így többek között a pszichológia, pedagógia és a szociológia felé is. A teológia örökérvényű igazságai mellett az elmúlt időszak közös együttgondolkodásai és kutatásai új hangsúlypontokat, és sok olyan megközelítési módot és módszertani fejlesztést hoztak, amely alapján érdemes újragondolni az egyetemeken folyó oktatómunkát, valamint az egyetemi curriculumokat is.

Évente egymillió körüli nagyságrendben jelenik meg új könyv; naponta több mint hatmillió blogbejegyzés születik; több mint félmilliárd újságot jelentetnek meg, ${ }^{36}$ és sokszor ennyi hír, cikk és tanulmány kerül(het) elénk - az egyéb online és offline tartalmakat nem is számolva. „Ki gondolta volna, hogy eljön az idő, amikor a Yale egyetem könyvtárosai karjukat széttárva ezt mondják: 'Túl sok könyvünk van.?” És valóban. Nemrég sok könyvtár azért küzdött, hogy polcait megtöltse - sok esetben az sem számított, hogy milyen könyvekkel -, mára már a legtöbb könyvtár selejtez, és helyhiánnyal küzd. Az információ gyors terjedését drámaian szemlélteti Naisbitt: Amikor Lincoln elnököt lelőtték, a világ az Egyesült Államok nagy részén távírón keresztül kommunikált. 
Mivel nem volt kapcsolatuk Angliával, ezért öt napba telt, mire London hallott az eseményröl. Amikor Reagan elnököt meglötték, Henry Fairlie újságíró - aki a lövöldözéstől csupán egy háztömbnyire volt - telefonon értesült az esetről londoni szerkesztőjétől, aki a televízióban látta a merényletet, röviddel azután, hogy az bekövetkezett. ${ }^{37}$

Az információ gyors terjedése hatással van a létrehozott információ mennyiségére is. Az információ mennyisége mára már hatalmas méreteket öltött, és továbbra is olyan növekvő mértékben gyarapodik, hogy a szakemberek már nem tudnak lépést tartani a saját szakterületükön sem. Ez kérdést vet fel az oktatás területén is, hiszen ebben az információrengetegben úgy kell továbbadni a tudást, hogy annak mélysége is legyen. Peter Lyman megjegyzi, hogy akutatások üteme sokszor már olyan gyors, hogy a publikált tudás a nyomtatás idejére szinte már elavulttá válik (írja ezt 1991-ben!). Következésképpen a személyesen, informálisan, illetve konferenciákon zajló eszmecsere felértékelődik, aktualitásuk miatt nagyobb jelentőséggel bírnak az ilyen formában elhangzó információk. ${ }^{38}$

\section{Egyetem és könyvtár az élethosszig tartó tanulás támogatásában}

A mérleg egyik serpenyőjében áll a hatalmas mennyiségű információáradat, másik oldalon pedig ellensúlyként a naponta több milliárd tétellel lefuttatott Googlekeresések. De vajon egyensúlyba billen a mérleg? A keresőmotor mindig megadja a megfelelő válaszokat? A kor embere pedig mindig tudja, hogy hol, mit és hogyan keressen? Sok esetben látni, hogy bár a hallgatóknak van bizonyos szintü informatikai jártasságuk (pl. videót, zenét, filmet töltenek le; e-maileket küldenek), ennek ellenére azonban sokan nem tanulták meg, hogyan lehet hatékonyan megtalálni az információt; értékelni, szintetizálni és ötletekké formálni a találatokat. ${ }^{39}$

A könyvtárak oktatásban játszott szerepe átgondolásra szorul. Korábban az oktatás támogatóiként vettek részt az egyetemek életében: könyvek vásárlásával, kölcsönzésével, tájékoztatással. A technika fejlödésével azonban a könyvtárosoknak sok olyan készséget kellett elsajátítaniuk, amelyekkel az oktatás aktív(abb) résztvevőivé váltak (pl. adatbázis-építés, online kurzusok, e-learning rendszerek ismerete). David Lankes szerint a felsőoktatási könyvtáraknak egyedülálló szerepet kell játszaniuk abban, hogy a tudományterületek közötti határok átívelésével felismerjék, megismerjék és terjesszék a legújabb oktatási modelleket. ${ }^{40}$ Így több könyvtár szervez online kurzusokat az információs müveltség elmélyítésére, s többen aktívan részt vesznek a felsőoktatási e-learning rendszerek kezelésében is.

Tekintettel az információ gyors mértékű elavulására, a felsőoktatási intézmények felelőssége, hogy a szakma alapvető eligazodási pontjainak megismertetése mellett a tanulási stratégiákat is megtanítsák a hallgatóknak. Gee és Breivik arra a következtetésre jutottak, hogy, ha a feladat az, hogy megtanuljuk, hogyan kell tanulni, és hogyan kell elhelyezni a tanulást egy szélesebb társadalmi- és információs környezetben, akkor célszerü, hogy a könyvtárak váljanak ezen tanulási módok elsajátításának cent- 


\section{MÉszÁros KornÉLIA}

rumaivá. ${ }^{41}$ Így kapcsolódnak be a tanítási folyamatba az információs müveltség, és a kutatói készségek fejlesztésének segítésével. Fontos, hogy a hallgatók még a tanulmányaik alatt megismerjék az egyetemi könyvtár használatát, a szakterületi szoftvereket és adatbázisokat, az azokban való keresés módjait, valamint elsajátítsák a hatékony információkeresés és információ-értékelés technikáit.

$\mathrm{Az}$ információs műveltség oktatásának különböző modelljei vannak: találunk olyan intézményt, ahol választható kurzusként szerepel, és elvégzése után kreditet kapnak a hallgatók; van olyan egyetem, ahol egy-egy kurzusba építve szerepel az adott szűkebb terület kutatásmódszertani bemutatása; más helyeken tantervbe építve kötelező kurzusként, vagy éppen kredit nélküli online kurzusként látjuk a meghirdetést. Az oktatás során a helybeni használat sajátosságai, és jellemzői mellett kiemelt figyelmet kell fordítani azon információforrások megismertetésére, amelyek a képzés elvégzése után is a hallgatók rendelkezésére állnak, illetve a könyvtár távhasználati lehetőségeire. Ha a könyvtár jól végzi feladatát, akkor a hallgatók a nagybetűs életben is hasznosítani tudják majd ezeket a technikákat, hatékonyabb problémamegoldó készséggel rendelkeznek, kutatási kérdések esetén pedig nagyobb bizalommal fordulnak a könyvtárhoz, mint a nagyobb keresőmotorokhoz.

Fontos, hogy a könyvtár a már szolgálatban állók számára is adjon tájékoztatást a szolgáltatásairól a könyvtári honlapon, az egyházi médiában, az adott csoportok találkozási helyein (lelkészi munkaközösségek ülései, lelkészkonferenciák, pedagógus szakmai napok és konferenciák, diakóniai szakmai napok stb.). A szakterületeken jelentkező időhiány miatt fontos, hogy ezek az előadások lényegre törően, az adott területre vonatkozó információkat, adatbázisokat és ezek gyakorlati hasznosságát mutassák be. A könyvtári gyüjtemény interdiszciplináris volta miatt a közvetlen szakterülethez kapcsolódó kurrens irodalom elérése mellett számos határterületi témában lehetnek segítségre a szaktudományi adatbázisok és az információkeresési készségek. Az egyházi iskolákban tanító pedagógusok számára hasznos segítség lehet, ha szaktárgyuk mellé társítani tudják az egyház társadalmi tanítását (pl. teremtés-evolúció), vagy részletesebben tudják bemutatni az adott felekezet szempontjából kiemelt eseményt (pl. protestánsoknál a reformáció), vagy személyt (pl. adott felekezethez kapcsolódóan írókat, költőket, tudósokat). Ezek mellett pedig a különböző középiskolai versenyek és szakkörök, tehetséggondozó- és tehetségfejlesztő csoportok munkájához is jó támasz lehet az egyetemi könyvtár szolgáltatása. A szolgálatban álló lelkészek számára igehirdetési előkészítők, különböző alkalmakhoz (pl. ifúsági óra, bibliaóra) kapcsolódó vázlatok és segédanyagok, egy-egy szakterületi vagy évfordulós téma szakirodalmának megtalálásában nyújtanak segítséget a források. A diakónia területén dolgozó munkatársak a területen jelentkező etikai kérdésekhez kapcsolódóan találhatnak tanulmányokat, valamint az új és újabb feladatokhoz kapcsolódó példákat jó gyakorlatokra (pl.: óvodák és idősek otthonának együttmüködése, pszichiátriai betegek gondozása egyházi intézményekben). 
A könyvtár távoli szolgáltatásainak haszna a kurrens tudás elérésén túl a házi könyvtár kiegészítése is. A régebb óta szolgálatban állók otthoni könyvtárában megtalálható az alap szakirodalom, azonban az újabb megjelenések nem feltétlenül jutnak el hozzájuk. A könyvtári szolgáltatások használatával azonban a keresések során $\mathrm{az}$ „ismert” művek mellett az újabb kiadványok is megjelennek, illetve nagyobb valószínűséggel kerülnek a használó elé. Az érem másik oldala a jelenleg szolgálatban álók, illetve a még egyetemi éveiket taposó hallgatók, akik sok régebbi „alapirodalomhoz" már nem jutnak hozzá, mivel az adott könyvek kiadói forgalomban már nem kaphatók, a szűkös érdeklődési kör miatt pedig a kiadó nem tervezi a művek újbóli kiadását (pl.: Paul Tillich: Rendszeres teológia). Sok kiadó döntött a könyvek újbóli (fizikai) megjelentetése helyett az online publikálás mellett. (Így például Tillich könyvét elérhetjük az Osiris Kiadó adatbázisán keresztül.) Az „új” generáció házi könyvtárait a kurrens irodalom mellett így tudják kiegészíteni a régebbi megjelenésủ művekkel.

Korunk sokszor bizonytalan keretei között fontos, hogy az egyházak biztos és hiteles pontként tudjanak szolgálni. Különösen fontos ez akkor, amikor az emberek az életük boldog és gondterhes pillanatait osztják meg velük, emberi sorsokat (gyermekeket, betegeket, kiszolgáltatott helyzetben lévőket) bíznak rájuk. Ehhez fontos az intézményekben dolgozók munkájának teológiai megalapozottsága, ennek eredményeként pedig a hit kérdéseire nyitott munkatársak tanítványi közösségé formálása. A megfelelő munkavégzéshez nélkülözhetetlen, hogy az egyházi intézményekben dolgozó szakemberek naprakészen tudják tartani szakmai felkészültségüket, lehetőségük legyen az önképzésre és a folyamatos lelki és szellemi feltöltődésre. Az egyházi felsőoktatási intézménynek és könyvtárának elkötelezettnek kell lennie a gyülekezeti-, oktató-nevelö-, valamint diakóniai területen végzett munka minőségének biztosítása, a keresztény identitás erősítése, a munka színvonalának a kor kihívásaihoz igazodó folyamatos fejlesztése mellett. Ehhez kell igazítania képzéseit, továbbképzéseit. Az egyházi felsőoktatási könyvtár akkor lehet igazán eredményes, ha nemcsak az egyetem, hanem az egyház közösségének is tudásbázisa lesz, ha könyvtárosai generálspecialistaként mozognak a teológia és a határtudományok területén, ismerik az egyházat és figyelemmel tekintenek olvasóikra. Ekkor válhat eredményessé a magvetés, ekkor teremhet igazán gyümölcsöt az egyházi felsőoktatás és annak könyvtára - mind a hallgatók, mind az egyház, mind a társadalom számára.

\section{Irodalom és jegyzetek}

1. SIBA Balázs: Pasztorálteológia: a református lelkészi hivatás vizsgálata interjúk tükrében. Budapest, Károli Gáspár Református Egyetem, L’Harmattan, 2018. 15. p.

2. MÖLLER, Christian: Einführung in die Praktische Theologie, Tübingen, Francke, 2004. 25-28. p.

3. SIBA Balázs: i. m. 16. p. 


\section{MÉszÁros KornÉLIA}

4. Uo.

5. LUTHER Márton: Asztali beszélgetések, Budapest, Helikon, 1983. 222. p.

6. BÉKÉSI Andor: Kálvin szociáletikája. = Theológiai Szemle, 7. évf. 11-12. sz. 1964. 360-361. p.

7. REUSS Andás: Önképzés - dacolni a lehetetlennel. = Lelkipásztor, 90. évf. 8-9. sz. 2015. 292. p.

8. DANKASA, Jacob: Information-seeking behavior of clergy. The research, the results, and the future. = Journal of Religious \& Theological Information, 14. vol. 1-2. no. 2015.14. p.

9. DANKASA, Jacob: i. m. 25. p.

10. WICKS, Donald A.: The information-seeking behavior of pastoral clergy: A study of the interaction of their work worlds and work roles. = Library \& Information Science Research, 21. vol. 2. no. 1999. 205-226 p. Forrás: https://doi.org/10.1016/S0740-8188(99)00003-1 [2019. július 1.]

11. DANKASA, Jacob: i. m. 23. p.

12. REUSS Andás: i. m. 294-295. p.

13. ÉRFALVY Lívia: Pedagógusok a tudomány útján: Visszatekintés a kutató tanári mozgalom elmúlt öt esztendejére. $=$ Evangélikus nevelés, 15. évf. 2. sz. 2017. 25. p.

14. GREGESEN-LABOSSA György: Diakónia: „A kezek evangéliuma”. In: Szabó Lajos (szerk.): A közösségépítő lelkész. Budapest, Luther Kiadó, 2010. 189-190 p.

15. MIHÁLYFI Ákos: A papnevelés története és elmélete. 1. kötet. Budapest, Szent István társulat, 1896. 54. p.

16. PÁNGYÁNSZKY Ágnes: Tanítás és tanulás felnőttkorban: szemléletváltás a felnőttkatekézisben. Budapest, Evangélikus Hittudományi Egyetem, 2015. 198. p.

17. HIGTON, Mike: A theology of higher education. Oxford, Oxford University Press, 2012. 8. p. Forrás: https://doi.org/10.1093/acprof:oso/9780199643929.001.0001 [2019. július 1.]

18. SIBA Balázs: i. m. 90. p.

19. KODÁCSY-SIMON Eszter: Miért tart fenn az egyház iskolát? In: Szabó Lajos (szerk.): Teológia és oktatás. Budapest, Luther Kiadó, 2015. 184 p.

20. PAZMIÑO, Robert W.: Principles and practices of christian education. An evangelical perspective. Eugene, Oregon, Wipf and Stock Publishers, 2002. 22. p.

21. SIBA Balázs: i. m. 105. p.

22. PÁNGYÁNSZKY Ágnes: A keresztény közösségvezetés egyházban, gyülekezetben, diakóniában. = Lelkipásztor, 93. évf. 2018. 12. sz. 459. p.

23. KARLE, Isolde: Der Pfarrberuf als Profession: Eine Berufstheorie im Kontext der modernen Gesellschaft. Stuttgart, Kreuz Verlag, 2011. 242. p.

24. MÉRỎ László: Maga itt a tánctanár? Pszichológia, moralitás, játék és tudomány. Budapest, Tericum, 2015. 29. p.

25. SIBA Balázs: i. m. 97. p.

26. SIBA Balázs: i. m. 95. p.

27. SIBA Balázs: i. m. 96. p.

28. LUTHER, Martin: D. Martin Luthers Werke. 25. Bd. Graz, Akademische Druck und Verlagsanstalt, 1964. 106. p.

29. SIBA Balázs: i. m. 108. p 
30. DUNKLY, James: Theological libraries and theological librarians in theological education. In: ATLA Summary of Proceedings, 1991. 228. p.

31. DUNKLY, James: i. m. 228. p.

32. WAGNER-RAU, Ulrike: Auf der Schwelle: Das Pfarrramt im Prozess kirchlichen Wandels. Stuttgart, Kohlhammer, 2012. 33. p.

33. DOUGHERTY, Richard M. - DOUGHERTY, Ann P.: The academic library. A time of crisis, change, and opportunity. = Journal of Academic Librarianship, 18-19. vol. 6. no. 1993. 346. p. Forrás: https://doi.org/10.1016/0099-1333(93)90046-8 [2019. július 1.]

34. LANKES, David R.: The new librarianship field guide. Cambridge, Massachusetts, The MIT Press, 2017. 133. p. Forrás: https://doi.org/10.7551/mitpress/10433.001.0001 [2019. július 1.]

35. VIZI E. Szilveszter: A tudás ötévente megfeleződik. = Videotorium, 2009. május.19. Forrás: https://videotorium.hu/en/recordings/2438/a-tudas-otevente-megfelezodik [2019. május 10.]

36. Az adatok forrása a https://www.worldometers.info [2019. május 30.]

37. NAISBITT, John: Megatrends: ten new directions transforming our lives. New York, Warner Books, 1984. 15. p.

38. LYMAN, Peter: The library of the (not-so-distant) future. = Change, 23. vol. 1. no. 1993. 34. p. Forrás: https://doi.org/10.1080/00091383.1991.10570216 [2019. július 1.]

39. ROCKMAN, Ilene F.: Integrating information literacy into the higher education curriculum. Practical models for transformation. San Francisco, Jossey-Bass, 2004. 260. p.

40. LANKES, David R.: i. m. 133. p.

41. BREIVIK, Patricia Senn - GEE, E. Gordon: Libraries and learning. In: Breivik, Patricia Senn - Wedgeworth, Robert eds.: Libraries and the search for academic excellence. Metuchen, N.J., Scarecrow Press, 1988. 33. p.

Mészáros Kornélia könyvtáros, evangélikus teológus - 2011 óta dolgozik az Evangélikus Hittudományi Egyetem Könyvtárában, 2016 óta a könyvtár vezetője. 2016-tól az Egyházi Könyvtárak Egyesülése Felügyelőbizottságának elnöke, 2019-től a Luther Kiadó Igazgatótanácsának tagja. 